VERTAISARVIOITU

KOLLEGIALT GRANSKAD

PEER-REVIEWED

www.tsv.fi/tunnus

\title{
MEDIAKESKUSTELUN VÄLITTÄMÄ TAMPEREEN YLIOPISTON NIMENVALINTAPROSESSI OSALLISTUJIEN ROOLIEN, POSITIOIDEN JA ARGUMENTTIEN VALOSSA
}

Terhi Ainiala, Helsingin yliopisto

Tiina Räisä, Yrkeshögskolan Arcada

/ Ammattikorkeakoulu Arcada

Paula Sjöblom, Turun yliopisto

Artikkelissa tutkitaan instituution nimenvalintaprosessia mediajulkisuudessa. Taustalla on kolmen korkeakoulun, Tampereen yliopiston, Tampereen teknillisen yliopiston ja Tampereen ammattikorkeakoulun, yhdistymishanke vuosina 2016-2017. Aineistona on perinteisen ja sosiaalisen median tekstejä, joissa yhdistyvän yliopiston nimenvalinnasta keskustellaan. Nimineuvottelussa puheenvuoroja esitetään sekä annetuista rooleista että otetuista positioista. Roolit ja positiot paljastuvat puheenaiheista, puhujien määrittelyistä ja kielellisistä valinnoista. Nimineuvottelua käydään instituutioiden, kielen, brändin, paikallisuuden ja karnevalistisen naurun näkökulmista. Annetuissa rooleissa keskustellaan etenkin perinteisessä mediassa, ja otettujen positioiden puheenvuorot painottuvat sosiaaliseen mediaan. Median kiinnostus nimeä kohtaan on osaltaan vaikuttamassa siihen, mikä nimi uudelle yliopistolle lopulta valitaan.

Avainsanat: diskurssi, instituutio, medialisoituminen, nimi, puhujapositio

Kirjoittajien yhteystiedot:

Terhi Ainiala

Tiina Räisä

terhi.ainiala@helsinki.fi tiina.raisa@arcada.fi

Paula Sjöblom

paula.sjoblom@utu.fi 


\section{JOHDANTO}

Nimellään kohde tunnetaan, oli kyse henkilöstä, paikasta tai instituutiosta. Nimien käytöllä voidaan rakentaa yhteenkuuluvuutta ja toisaalta tehdä rajoja "meidän" ja "toisten" välille (esim. Ainiala \& Halonen, 2011; Ainiala \& Lappalainen, 2017). Mediajulkisuudessa esiintyvät nimet muokkaavat käsitystämme suomalaisesta yhteiskunnasta ja sen keskeisistä toimijoista (Räisä, 2016). Nimen antaminen taas on prosessi, jossa nimeä ideoidaan, ideoita vertaillaan ja testataan, nimestä päätetään ja se vakiinnutetaan. Prosessi voi olla joskus pitkä ja työläs, koska nimen valinnalla tehdään myös nimettävän identiteettiin liittyviä ratkaisuja.

Tässä nimistöntutkimuksen eli onomastiikan alaan kuuluvassa artikkelissa tutkimme instituution nimenvalintaprosessia mediajulkisuudessa. Työtämme kehystää kolmen korkeakoulun, Tampereen yliopiston (TY), Tampereen teknillisen yliopiston (TTY) ja Tampereen ammattikorkeakoulun (TAMK), yhdistymishanke vuosina 2016-2017.

Tutkimamme tapaus sai alkunsa keväällä 2014 Tampereen korkeakoulujen omasta aloitteesta. Stig Gustavsonin vetämä, vararehtoreista koostuva selvitysryhmä kannatti yhdistymistä, ja opetusministeri Sanni GrahnLaasonen asetti 21.2.2016 ohjausryhmän valmistelemaan asiaa. Tampereen korkeakoulusäätiö perustettiin 20.4.2017. Uusi, yhdistynyt yliopisto aloitti toimintansa tammikuussa 2019 tunnuslauseenaan "Ihminen ratkaisee". Prosessi sai matkan varrella runsaasti kritiikkiä etenkin entisen Tampereen yliopiston henkilöstöltä.

Aluksi yhdistymisprojekti kulki nimillä T3 ja Tampere3. Vuonna 2016 korkeakoulut järjestivät nimikilpailun ja Aamulehti oman nimiäänestyksen, ja molempiin tuli satoja vastauksia. Samana vuonna TTY:n hallitus esitti nimeksi Tampereen uutta yliopistoa (engl. Tampere New University). Nimi sai kannatusta myös TY:n hallituksessa, ja säätiöyliopiston perustamisen yhteydessä kolmen korkeakoulun hallitukset esittivät sitä yliopiston uudeksi nimeksi. Korkeakoulusäätiön hallitus ja korkeakoulujen hallitukset hylkäsivät kuitenkin nimen vielä samana syksynä ja ehdottivat eduskunnan sivistysvaliokunnalle nimeksi Tampereen yliopistoa (Tampere university), joka sitten sinetöitiin.

Tarkastelemme yhdistymisprosessia sellaisena, kuin se ilmenee julkisuudessa nimestä käytävässä neuvottelussa. Neuvottelu on prosessinomaista toimintaa, jolla on jokin yhteinen tavoite (tässä nimen löytäminen) ja jossa kaikki osapuolet ovat jossain määrin motivoituneita ratkaisemaan kysymyksen ja mahdolliset eturistiriidat (Kangasharju, 1991, s. 12-14). Tutkimuksemme tavoitteena on selvittää, millainen prosessi perinteisessä ja sosiaalisessa mediassa käytävä nimineuvottelu on osana korkeakoulujen yhdistymisprosessia. Neuvottelun osapuolina ovat paitsi kolme yhdistyvää instituutiota myös mediainstituutio itse sekä kaikki yksilöt, jotka osallistuvat keskusteluun. Mediaa pidämme itsenäisenä instituutiona sen vakiintuneen, ammattimaisen ja kulttuurisidonnaisen toimintatavan vuoksi (Hjarvard, 2013, s. 24). Sille keskeistä on huomion herättäminen, joten instituutiona se ei ole juridinen tai fyysinen organisaatio vaan merkityksiä rakentava järjestelmä (Couldry \& Hepp, 2017, s. 25). Tutkimuskysymyksemme ovat seuraavat: Ketkä saavat tai ottavat nimineuvottelussa puheenvuoron ja millaisista rooleista tai positioista nimeen otetaan kantaa? Millaista retoriikkaa ja millaisia argumentteja eri puhujarooleissa ja -positioissa käytetään?

Aineistomme koostuu perinteisen ja sosiaalisen median teksteistä. Käytössämme on ajalta 1.4.2016-21.2.2018 yhteensä noin 200 Facebook- ja Twitter-keskusteluviestiä sekä 23 perinteisen median uutisartikkelia, jotka 
on julkaistu Aamulehdessä (11 artikkelia), Helsingin Sanomissa (5), Ylen verkkosivulla (4) ja Tampereen ylioppilaslehdessä Aviisissa (7). Aamulehden ja Helsingin Sanomien Facebook-sivuilta on poimittu yhdistyvän korkeakoulun nimestä käydyt keskustelut. Twitter-palvelusta on puolestaan poimittu keskustelut haulla "Tampere yliopisto nimi”.

Tutkimuksen teoreettis-metodisena pohjana on retorinen diskurssianalyysi (esim. Burke, 1962; Pälli, 2003). Diskurssianalyysin avulla pyritään selvittämään sosiaalisen todellisuuden rakentumista kielenkäytössä. Ns. uusi retoriikka tarkastelee kielen keinoja, joilla puhuja vahvistaa väitteidensä uskottavuutta. Näiden menetelmien yhdistelmä luontuu hyvin media-aineiston ja siinä ilmenevien sosiaalisten prosessien ja valtasuhteiden tarkasteluun (Jokinen, 2002, s. 38-40, 43, 46; ks. myös Perelman, 1996, s. 11-12).

Tutkimuksemme kytkeytyy myös kansanonomastiseen tutkimukseen (esim. Ainiala \& Östman, 2017; Aldrin, 2018), jonka fokuksessa ovat nimiä ja niiden käyttöä koskevat käsitykset ja havainnot. Analyysin tuloksia tarkastellaan lopuksi myös medialisoituneen kulttuurin näkökulmasta, johon oletamme uuden yliopiston nimenannon kytkeytyvän (Couldry \& Hepp, 2017; Fornäs, 2011; Hjarvard, 2013). Media kontekstina antaa mahdollisuuden pohtia myös nimien julkista roolia ja nimien merkitystä instituutioille.

\section{YLIOPISTON NIMI MONIALAISENA TUTKIMUSKOHTEENA}

\subsection{Yliopiston nimi nimistöntutkimuksen näkökulmasta}

Tutkimamme kohteet ovat korkeakouluja. Oppilaitosten nimiä on nimistöntutkimuksessa tarkasteltu melko vähän (ks. kuit. Hä- mäläinen, 2015; Sommerfeldt, 1994), joten yhtymäkohtia tulee etsiä muita nimikategorioita koskevasta tutkimuksesta. Nimistöntutkimuksen oppikirja (Ainiala, Saarelma \& Sjöblom, 2008) jakaa nimet perinteiseen tapaan henkilönnimiin, paikannimiin, kaupallisiin nimiin, eläinten nimiin ja kaunokirjallisuudessa esiintyviin nimiin. Oppilaitosten ja muiden instituutioiden nimet eivät sovi tarkasti mihinkään näistä luokista, mutta nimien luokitteluun on muitakin tapoja. Eräästä näkökulmasta voidaan erottaa henkilön-, eläinten- ja luontonimien lisäksi kulttuurinimien laaja kirjo alaryhmineen. Yksi näistä alaryhmistä on organisaatioiden nimet, joiden tarkoitteita ovat mm. yhdistykset, laitokset, arkistot ja yritykset (Sjöblom, 2006, s. 48-50). Näihin kuuluvat luontevasti myös korkeakoulujen nimet. Korkeakoulut ovat organisaatioina virallisen, julkisen vallan instituutioita, joten kutsumme niiden nimiä myös instituutioiden nimiksi.

Instituutioiden nimet ovat myös virallisia nimiä. Virallista nimistöä ovat viranomaispäätöksellä hyväksytyt nimet, esimerkiksi kuntien viranomaisten sekä ministeriöiden, virastojen, laitosten, säätiöiden ja muiden organisaatioiden rekisteröidyt nimet. Yliopistojen nimet hyväksyy Suomen eduskunta, koska nimet on kirjattu yliopistolakiin (558/2009, 1 luku, \$1). Virallisia nimiä säätelevät perustus-, kieli- ja hallintolain vaatimukset asiallisesta, selkeästä ja ymmärrettävästä kielestä. Viralliset nimet ovatkin nimistönhuollon ensisijaisia kohteita (Kotus.fi: virallinen nimistö).

Yliopistot, kuten monet muutkin oppilaitokset, toimivat yritysten tapaan globaalissa kilpailutilanteessa: ne kilpailevat parhaista opiskelijoista, henkilökunnasta, ulkopuolisesta rahoituksesta ja näkyvyydestä. Tämä näkyy myös tutkimassamme tapauksessa, jossa sekä tavoitellaan virallisilta nimiltä edellytettävää informatiivisuutta että pyritään kaupallisten 
nimien lailla houkuttelevuuteen. Kaupalliset tavoitteet eivät ole välttämättä ristiriidassa virallisilta nimiltä edellytettävän selkeyden kanssa. Monista informatiivisista tai muuten selvästi ymmärrettävistä nimistä on muodostunut arvostettuja brändejä (esim. Handelsbanken, Veikkaus, Kone). Toisaalta varsinkin 2000-2010-luvuilla viranomaiset ja instituutiot ovat selkeyden kustannuksella halunneet brändätä itseään erottuvan ja mieleenpainuvan, mutta samalla kohdettaan kuvaamattoman, nimen avulla (esim. Destia, Metropolia, Traficom). Näin siitä huolimatta, että näistä nimistä on annettu monia kielenhuollollisia suosituksia (ks. Hämäläinen, 2015;_Onkamo, 2017a; Onkamo, 2017b; suosituksista Kotus. fi: oppilaitosten nimet).

Kaikkien erisnimien perusfunktio on kohteen yksilöinti eli erottaminen muista samanlajisista kohteista. Yksilöintifunktio toteutuu, oli nimen muoto mikä hyvänsä, kunhan se eroaa riittävästi muista vastaavista. Nimillä on kuitenkin myös muita funktioita. Yleensä kieliyhteisölle ei ole yhdentekevää, minkälaisista elementeistä nimi koostuu: esimerkiksi yrityksen nimi sisältää usein sanan, joka paljastaa yrityksen toimialan. Nimillä on näin niihin sisältyvien sanojen merkityksiin liittyviä, sosiokulttuurisia tai emotiivisia tehtäviä (Sjöblom, 2006, s. 69-70).

Henkilönnimen valinta on tapa asemoida yksilö sosiaalisesti, ja nimenanto on yleensä monivaiheinen prosessi. Lapsen etunimeä koskevassa neuvottelussa ja nimenantoprosessissa voidaan nähdä eri vaiheita: inspiraatio, vertailu, testaus, päätös, vakiinnuttaminen ja narratiivinen vaihe (Aldrin, 2011, s. 35-42). Nimi on kytköksissä henkilön identiteettiin. Valitessaan lapselleen nimeä vanhemmat rakentavat tietoisesti tai tiedostamattaan tälle tietynlaista identiteettiä, vaikka toisaalta nimenvalinnan voi ajatella heijastelevan pikemmin nimenantajien identiteettiä (mt.: 225-233). Myös erilaiset henkilön identi- teetissä tapahtuvat muutokset voivat johtaa nimen muuttamiseen. Viime aikoina on selvitetty esimerkiksi transsukupuolisten aikuisten nimenmuutosprosessien dynamiikkaa. Näissä tapauksissa uuden nimen valintaprosessi poikkeaa jossain määrin lapsen nimenantoprosessista, koska nimenvalinta on tiedostetummin kytköksissä henkilön omaan identiteettiin ja koska entinen nimi vaikuttaa uuden nimen valintaan. (esim. Leino, 2014; SchmidtJüngst, 2015).

Myös paikannimellä voi olla tiukka kytkös sekä paikan identiteettiin että paikan asukkaiden identiteettiin. Vanhat paikannimet edustavat jatkuvuutta ja pysyvyyttä. Esimerkiksi kuntaliitosten yhteydessä tapahtuneiden nimenmuutosten ankara vastustus johtuu ainakin osittain siitä, että asukkailla on syvä tunnesuhde oman kotikuntansa nimeen ja he pelkäävät paikan menettävän historiansa ja houkuttelevuutensa nimen mukana (Hakala, Sjöblom \& Kantola, 2015, s. 263, 265; Sjöblom \& Hakala 2018, s. 142-143).

Instituution nimeä koskevaan julkiseen keskusteluun liittyy samoja piirteitä kuin keskusteluun kunnan nimestä. Näkemyksemme mukaan nimi on yksi niistä asioista, jotka paljastavat, miten instituutio asemoituu yhteiskuntaan. Nimen avulla yliopisto rakentaa itselleen uutta identiteettiä, jonka aineksina voivat toimia yhdistyvien korkeakoulujen tausta ja perinteet. Uuteen nimeen ei siirrytä suoraan vaan monen askeleen kautta. Nimensä avulla instituutio hankkii myös legitimiteettiä toimijana, vaikka neuvottelu voikin synnyttää jännitteitä nimestä päättävien ja muun yhteisön välillä. Nimenvalinnasta käytävä julkinen keskustelu antaa aikaa itse instituution synnyttämiselle ja toisaalta mahdollistaa instituution identiteetin muotoilemisen.

Prosessina instituution nimenvalinnalla on yhtymäkohtia henkilönnimen - etenkin aikuisen uuden nimen - valintaan, joskin eri 
mittakaavassa. Koska nämä vaiheet eivät sellaisinaan esiinny tutkimassamme tapauksessa, jaamme yliopiston uuden nimen löytämisen vaiheet seuraavasti: työnimivaihe, varsinaisen nimen keksimisvaihe, nimen tunnetuksi tekemisen vaihe, nimen hyväksymisvaihe ja nimen käyttöönottovaihe. Vaiheittainen eteneminen heijastaa ihmisten vaikeutta hyväksyä äkillisiä muutoksia: nimeen tottuminen vaatii aikaa.

\subsection{Teoreettiset ja metodiset kehykset}

Uuden yliopiston mahdollisista nimistä keskustellaan tutkimassamme tapauksessa moninaisesti. Kun selvitämme sitä, millaisia käsityksiä ja havaintoja keskustelijoilla nimistä on, teemme kansanonomastista tutkimusta. Siinä nimiä koskeva puhe jaetaan joko itse nimiä ja nimielementtejä koskevaksi (metakieli 1) tai nimienkäyttöön ja nimenkäyttäjiin liittyviin uskomuksiin (metakieli 2) (Ainiala \& Halonen, 2011; Ainiala \& Östman, 2017). Edelliset luonnehdinnat kohdistuvat nimen leksikaaliseen tai muuhun kielelliseen sisältöön ja ulkoasuun (nimet sellaisinaan), jälkimmäiset nimen käytettävyyteen (nimet välineinä).

Varsinaisena metodinamme on retorinen diskurssianalyysi, jonka avulla selvitämme, millaisin argumentein ja millaisin retorisin keinoin nimivaihtoehtoja puolletaan tai tyrmätään. Diskurssianalyysi perustuu ajatukseen, että ihmiset hahmottavat ja rakentavat todellisuutta sosiaalisessa vuorovaikutuksessa. Kielellä tuotetaan kulttuurisia merkityksiä ja merkitysten tulkinnat syntyvät vuorovaikutuksessa (Jokinen, 2002, s. 47, 59). Tässä tutkimuksessa analyysi pureutuu yksityiskohtaisimmin kielen käyttöön, lausumien muotoiluun, siihen miten kielellisten ilmausten valinta rakentaa todellisuutta - eli retoriikkaan. Retoriikka taas liittyy kiinteästi argumentointiin. Argumentoinnilla puhuja pyrkii vakuuttamaan kuulijat väitteidensä takana olevien arvojen, premissien eli esisopimusten hyväksyttävyydestä ja uskottavuudesta (Perelman, 1996, s. 28). Premissejä koskeva hyväksyntä sidotaan johtopäätöksiin kolmenlaisin argumentein: loogiselta näyttävin argumentein, syy-seuraus- tai vastaaviin suhteisiin perustuvin argumentein tai yleistämällä yksittäistapauksia säännöksi (mt. s. 59-60, 93).

Kenneth Burken (1962) mukaan retoriikka perustuu identifikaatioon eli siihen, että puhuja samastuu ja pyrkii samastamaan kohdeyleisönsä tiettyyn ryhmään. Ryhmään samastuminen on tietyn puhujaposition ottamista. Retoriikka on siis kielellisiä valintoja, jotka muokkaavat sosiaalista identiteettiämme. Tässä tarkasteltavaan nimineuvotteluun osapuolet tuovat eri näkökulmia, jotka antavat valittavalle nimelle erilaisia sosiaalisia merkityksiä. Ne puolestaan kytkeytyvät tulkintoihin senhetkisten korkeakoulujen ja niiden yhdistyessä syntyvän uuden yliopiston identiteeteistä.

Tarkastelemme lopuksi kielellisen analyysin tuloksia myös medialisoitumisen näkökulmasta: median ja yhteiskunnan tiiviinä ja kompleksisena suhteena. Emme analysoi nimenantoa medioituneena viestintänä eli teknisenä ja välitteisenä keskusteluna. Sen sijaan fokuksessa on medioituneen viestinnän määrän ja laadun mukanaan tuomat pitkäjänteiset seuraukset ja muutokset eli medialisoituminen (Couldry \& Hepp 2017, s. 35; Sumiala, 2012, s. 113). Mediassa käytävä nimikeskustelu on yksi esimerkki siitä, kuinka merkitykset rakentuvat median ehdoilla ja median prosesseina. Medialisoitumisessa painottuu mediakeskustelun moniäänisyys, yhtäaikaisuus ja ristiriitaisuus, sen monet tasot ja ulottuvuudet (Couldry \& Hepp, 2017, s. 17, 22; Hjarvard, 2013, s. 2).

Emme siis ota kantaa korkeakoulujen sisäiseen nimikeskusteluun ja päätöksentekoon, vaan selvitämme nimenvalintaprosessin etenemistä sellaisena kuin se näyttäytyy me- 
diakeskustelua seuraavalle yksilölle. Korkeakoulut ovat instituutioita, joiden toimivalta näyttäytyy $\mathrm{mm}$. oikeutena valita itselleen nimi (vrt. Bourdieu, 1991, s. 105-106). Medialisoitumisen kannalta on olennaista, millä tavalla nimestä neuvotellaan suhteessa mediassa esitettyihin argumentteihin ja median logiikkaan eli median arvostusten, formaattien ja rutiinien (Hjarvard, 2013, s. 11) mukaisesti eri alustoilla. Korkeakouluille taas on oleellista, että ne saavat viestinsä onnistuneesti esille.

\section{PUHUJIEN POSITIOT, ROOLIT JA ARGUMENTIT}

Otamme tarkastelun lähtökohdaksi neuvottelijoiden roolit ja puhujapositiot. Eri ryhmien jäsenyyksiä merkitään teksteissä erilaisin kielellisin keinoin, kuten nimeämällä (kansa, eliitti), me-puheella (uskomme) tai predikatiiviadverbiaaleilla (esim. entisenä urheilijana olen - -) (Virsu, 2007, s. 355-357). Tarkasteltavissa teksteissä osa puhujista on ikään kuin istutettu tiettyyn rooliin ulkoapäin, kun taas osa keskustelijoista ottaa itse aseman tietyssä ryhmässä, josta käsin esittää nimivaihtoehtoja koskevia argumentteja. Erottelemme nämä analyysissamme käsittein annetut roolit ja otetut pubujapositiot.

Nimikeskusteluja analysoimalla olemme löytäneet viisi ryhmää, joiden jäseneksi puhuja mediassa joko asetetaan (rooli) tai asettuu (positio). Esittelemme nämä ryhmät seuraavassa (ks. taulukko 1). Eri puhujarooleista ja -positioista esitettyjä argumentteja ja retoriikkaa selvitetään luvuissa 3.1-3.5.

TAULUKKO 1. Nimineuvottelun positiot ja roolit.

\begin{tabular}{|l|l|l|}
\hline Puhujan asema & Otetut positiot & Annetut roolit \\
\hline Instituutioiden edustajat & $\begin{array}{l}\text { opetus- ja tutkimus- } \\
\text { henkilökunta }\end{array}$ & $\begin{array}{l}\text { rehtorit, kaupungin edustajat, } \\
\text { ministeri, hankejohtaja yms. }\end{array}$ \\
\hline Kielen asiantuntijat & "kielipoliisit" & $\begin{array}{l}\text { alan koulutuksen saaneet, } \\
\text { alalla toimivat tai sitä tuntevat }\end{array}$ \\
\hline Brändinrakentajat & "markkinoijat" & $\begin{array}{l}\text { alan koulutuksen saaneet, } \\
\text { alalla toimivat tai sitä tuntevat }\end{array}$ \\
\hline Paikallisuuden ystävät & "tamperelaiset" & - \\
\hline Karnevalistit & $\begin{array}{l}\text { sosiaalisen median } \\
\text { vitsiniekat }\end{array}$ & $\begin{array}{l}\text { aprillipäivän jutun kirjoittaja, } \\
\text { HS NYT-liitteen jutun kirjoittaja }\end{array}$ \\
\hline
\end{tabular}


Instituutio itsessään on nimineuvottelun keskeinen osapuoli. Instituution edustajan rooli osoitetaan teksteissä institutionaalisin tittelein, kuten rebtori, hankejohtaja, ministeri. Instituutioiden edustajiksi positioituvat myös ne keskustelijat, jotka mainitsevat tavalla tai toisella kuuluvansa korkeakouluyhteisöön. Media asettuu tässä kuviossa keskustelua ylläpitävän ja kontrolloivan instituution positioon, ja se on samalla voimakas roolien asettaja ja vakiinnuttaja.

Kielen asiantuntijan - ja samalla nimistöasiantuntijan - rooli annetaan mediassa henkilölle mainitsemalla asema, tehtävänimike, kieleen liittyvä koulutustausta tai alan pitkä kokemus (Tampereen yliopistossa yli 20 vuotta suomen kielen ja kielenhuollon lebtorina toiminut; Twitterissä ja Facebookissa Kielipoliisina [sic!] vaikuttava suomen kielen maisteri). Myös muulla kuin kieleen liittyvällä koulutuksella tai asemalla voi päätyä kielen asiantuntijan rooliin tai puhujapositioon, kun puheenaiheeksi valikoituu jokin kieleen liittyvä piirre (äänteet, taivutus yms.).

Brändinrakentajan rooli nousee näkyviin puheenvuoroissa, joissa käytetään markkinointiin liittyvää sanastoa, kuten brändiammattilainen, koulutusmarkkinointi, myyminen. Yleensä tähän rooliin liittyy myös institutionaalinen tai koulutuksen tai kokemuksen kautta saatu asema. Vain jokunen verkkokeskustelija kommentoi nimiä markkinointinäkökulmasta ja asettuu näin osittain brändinrakentajan positioon.

Paikallisuuden ystävän rooliin ei perinteinen media näytä asettavan ketään, mutta sen sijaan tästä puhujapositiosta esitetään sosiaalisen median kanavilla lukuisia kommentteja, mikä näkyy moninaisina, Tampereeseen suoraan tai välillisesti liittyvinä kielellisinä ilmauksina. Tämä puhujapositio otetaan poikkeuksetta itse, eikä sosiaalisen median keskustelussa ketään toista aseteta tähän rooliin.
Karnevalistin rooli on toimittajalla, joka kirjoittaa humoristiseksi tarkoitetun jutun mediaan. Moni sosiaalisessa mediassa kommentoiva asettuu karnevalistiseen puhujapositioon, mikä näkyy esimerkiksi yllättävinä sanavalintoina, sanojen vääntelynä ja muina sanaleikkeinä tai liioitteluna.

\subsection{Instituutioiden edustajat}

Instituutioita edustavat aineistossamme pääasiassa Tampereen yliopiston ja Tampereen teknillisen yliopiston rehtorit sekä kaupungin ja valtion edustajat. Heidän puheenvuoronsa sisältävät lausuntoja, selityksiä ja korjausliikkeitä. Perinteiset uutismediat antavat heille paljon näkyvyyttä.

Nimenantoprosessin työnimivaihetta edustavat projektinimet T3 ja Tampere3, jotka ilmaisevat fuusioituvien korkeakoulujen lukumäärän. Uuden instituution nimeen liittyvät uutiset herättävät uteliaisuutta ja kiinnostusta (esimerkki 1).

(1) Asiat etenevät. Uteliaana tietysti kyselen, että koskas uuden yliopiston nimi päätetään. (Twitter 9.8.2016)

Ammattikorkeakoulun edustajat esiintyvät aineistossa vain prosessin alkuvaiheessa. Vuonna 2015 TAMK:n rehtori Markku Lahtinen puhuu Helsingin Sanomissa (esimerkki 2). Hän ei pidä ongelmana, että uuden nimen myötä myös osa korkeakoulun omasta identiteetistä saattaa kadota, vaan lukee tulevan nimen pragmaattiseksi ratkaisuksi. Puhuja siis torjuu olettamansa vasta-argumentin, instituutioiden eriarvoisen aseman, ja keskittyy argumentoimaan faktojen avulla koko yhdistymishankkeen puolesta ja asemoimaan uutta yliopistoa globaaleilla korkeakoulumarkkinoilla. 
(2) "Ei sen ammatillisuuden tarvitse näkyä nimessä, vaan tutkintojen sisällössä. Tämä on pragmaattinen ratkaisu." Lahtinen sanoo ja viittaa siihen, että jos yhteistyössä tavoitellaan yhtä organisaatiota, sen on syytä olla yliopisto, koska yliopistolla on perustuslain turvaama autonomia. - - "Ja kansainvälisestihän sana university on tunnetumpi", Lahtinen huomauttaa. (HS 25.5.2015).

Keksimisvaiheessa nimenantoprosessi vauhdittuu, kun T3-hanke julkistaa oman nimikilpailunsa.

(3) Onko sinulla suuri visio uuden yliopiston nimeksi? Nyt kannattaa jakaa parhaat ideat, sillä yliopiston nimikilpailu on vielä vappuun asti auki. Tampere 3 hankejohtaja Päivi Myllykangas sanoo, että ehdotuksia on tullut tähän mennessä reilut 300. Pääasiassa ehdotukset ovat olleet asiallisia ja hyviä. (Aviisi 12.4.2016).

(4) Kolmen oppilaitoksen henkilöstöltä, opiskelijoilta ja sidosryhmiltä on kerätty nimiehdotuksia uudelle korkeakouluyhteisölle. Vastauksia hanketoimistolle on tullut lähes 500. Kärkipäähän ovat kirineet $\mathrm{mm}$. Tampereen yliopisto, Tampereen uusi yliopisto, Koskiyliopisto ja Linna (Yle 30.9.2016).

Nimikilpailu on tietysti käytännöllinen tapa kerätä ideoita. Tätä olennaisempaa on, että instituutio ottaa aktiivisen roolin ja käyttää nimikilpailua osoittaakseen yhteiskuntaa kohtaan avoimuutta ja yhteistyökykyä. Osallistamista voi pitää myös sitouttamisen välineenä. Esimerkeistä 3-4 näkyy, että nimikilpailun avulla rakennetaan luottamuksellista suhdetta yleisöön puhuttelemalla lukijaa ja luomalla vaikutelmaa yleisöäänestyksestä (Kärkipäähän ovat kirineet). Retoriikassa ko- rostuvat sekä laadulliset (asiallisia ja hyviä) että määrälliset (reilut 300 [ehdotusta]); lähes 500 [vastausta]) argumentit.

Keksimisvaihetta luonnehtii arvuuttelu. Varsinkin perinteisessä mediassa korkeakoulut näyttävät etääntyvän toisistaan. Rehtori Liisa Laakson suulla TY:n hallitus tulkitsee teknillisen yliopiston kantaa tulevaan nimeen: Tampereen yliopisto tuskin saa kannatusta (AL 8.10.2016). Sosiaalisessa mediassa instituutioiden edustajat voivat keskustella suoraan, ilman portinvartijana toimivaa uutismediaa, kuten esimerkissä 5, jossa TY:n rehtori esittää suoran kysymyksen TTY:n rehtorille Mika Hannulalle.

(5) Liisa Laakso: Mikä nimi uudelle yliopistolle? (sic!) \#tampere3 ping @mika hannula (Twitter 5.4.2016)

Nimenantoprosessi kriisiytyy ensimmäisen kerran, kun yliopistot ehdottavat eri nimiä: TTY nimeä Tampereen uusi yliopisto ja TY nimeä Tampere-yliopisto. Jälkimmäinen herättää yleistä hämmennystä ja vastarintaa. Aamulehti julkaisee 8.10.2016 aiheesta kolme artikkelia, joista yksi on lehden oma nimiäänestys, ja se myös oikaisee ensimmäisessä jutussa esiintyneen yhdysmerkittömän muodon Tampere yliopisto. TY:n rehtori väittää, että julkisuuteen päätynyt nimi on virhe (6). Sekaannuksesta (vä̈rinymmärrys) yliopistoinstituutio syyttää toista instituutiota, mediaa (yhdysmerkistä ei erikseen mainittu). Aamulehti oli asemoitunut aktiiviseksi toimijaksi jo edeltävänä päivänä julkaisemalla Facebookissa päivityksen, jossa se kysyi lukijoiltaan Miltä kuulostaisi Tampere yliopisto?. Sosiaalisessa mediassa eri nimiasuihin (yhdysmerkin kera ja ilman) suhtaudutaan kriittisesti (7).

(6) Tampereen yliopiston rehtori Liisa Laakso viestitti Aamulehdelle lauantaina, että Tampereen yliopiston hallituksen ni- 
miehdotus on Tampere-yliopisto yhdysmerkillä, ei suinkaan Tampere yliopisto, niin kuin Aamulehdessä aikaisemmin kerrottiin. Väärinymmärrys syntyi puhelinhaastattelussa, jossa yhdysmerkistä ei erikseen mainittu. (ALb 8.10.2016).

(7) \#tampere3 Mitäs täällä valitetaan, Tampere Yliopisto on ihan yhtä pätevä nimi kuin Elämän koulukin (Twitter 8.10.2016)

Kielellisesti hankala nimi suistaa nimenantoprosessin ja samalla yhdistymishankkeen raiteiltaan, ja hankkeesta aletaan esittää entistä kriittisempiä puheenvuoroja. Kömpelö nimi muuttaa instituutiodiskurssia kyseenalaistaen uuden yliopiston legitimiteetin.

Median instituutionaalista asemaa osoittaa, että Aamulehden toimittaja Kimmo Koski osallistuu keskusteluun ehdottamalla uudelle yliopistolle nimeä. Lehti ottaa itsenäisen roolin puhuessaan kuin nimistöasiantuntija ja arvostellessaan yliopistojen yhdistymishanketta (8).

(8) Nimet tekevät näkyväksi, kuinka vaikeaa erilaisten korkeakoulujen yhdistäminen on.

Nimet kertovat enemmän projektin ilmeisistä jännitteistä kuin uudesta kansainvälisestä korkeakoulusta. - - On selvää, että jos Tampere halutaan nimessä säilyttää, ainoa vaihtoehto on Tampereen yliopisto. - - Sukunimestäni huolimatta rohkenen ehdottaa uuden yliopiston nimeksi Koskiyliopistoa, englanniksi Koski University. (AL 12.10.2016).

Media määrittää siis, mikä on hyväksi muille instituutioille eli yliopistolle ja kaupungille. Media tuo näkyvyyttä hankkeelle, ja keskittyessään tunteita herättävään nimiasiaan se hankkii näkyvyyttä myös itselleen.
Tunnetuksi tekemisen vaihe alkaa, kun uuden yliopiston perustamisjuhlassa Tampereen pormestari Anna Kaisa Ikonen paljastaa virallisen nimen: Tampereen uusi yliopisto, englanniksi Tampere New University (AL 20.4.2017). Myös Helsingin Sanomat (20.4.2017) osallistuu keskusteluun uutisella, jossa Tampereen kaupungin erityisasiantuntija Pekka Kivekkäälle annetaan instituution edustajan rooli. Hän käyttää kaupungin äänenä mm. ilmauksia tyytyväinen lopputulokseen, täytyy olla onnellinen ja kaikki on byvä mitä asiasta kuulee. Perinteisessä mediassa nimenantoprosessi on hetken instituutioiden käsissä ja konsensus vallitsee. Korkeakoulujen, säätiön ja kaupungin edustajien lisäksi instituutioita edustaa mediassa myös Teknologiateollisuus ry:n puheenjohtaja Risto Siilasmaa. Instituutiot liittyvät yhteen symbolisesti tärkeän nimen kautta.

Instituutioiden hyväksymä nimi ei kuitenkaan saa kannatusta sosiaalisessa mediassa, jossa sitä kritisoidaan kuuluvasti. Julkistamista ei seuraa hyväksymis- tai käyttöönottovaihe vaan toinen kriisi. Kertaalleen sovittu nimi hylätään. Korkeakoulusäätiön hallituksen uusi puheenjohtaja Marja Makarow tuo esille nimeen liittyvät ongelmat (9-10). Samalla kerrotaan, että uudeksi nimeksi tulee Tampereen yliopisto - Tampere University.

(9) Tampere 3-säätiön puheenjohtaja Marja Makarowin mukaan yliopistoyhteisö alkoi epäillä sanojen "uusi" ja "new" käyttöä ja ehdotti hallitukselle nimen vaihtamista. (Aviisi 14.9.2017)

(10) "Kun Tampereen korkeakoulusäätiön hallitus nimettiin kesällä, meidät tietysti briifattiin aiemmasta keskustelusta ja nimivaihtoehdoista, jotka olivat olleet käsiteltävinä. 'Tampereen uusi yliopisto' oli pyöritellyistä nimistä numero yksi. Mutta sitten tämä yhteisö oli tullut uusiin 
ajatuksiin sanan 'uusi' suhteen, Makarow pohjustaa. Me pohdimme asiaa hallituksessa, ja tulimme samaan tulemaan kuin korkeakouluyhteisö. Sana 'new' on hyvä poistaa nimestä.” (HS 14.9.2017)

Instituution näkökulmasta aiemmassa päätöksessä ei senhetkisen tiedon valossa ollut vikaa. Yliopistoyhteisö onkin instituutiosta erillinen vastapuoli, joka olisi ikään kuin muuttanut mieltään, minkä jälkeen me yliopistoinstituutiona pohdimme asiaa ja tulimme samaan tulemaan.

Nähdään siis useita nimiä, ennen kuin instituutiot pääsevät yhteisymmärrykseen ja nimi siirtyy institutionaalisia portaita eteenpäin käyttöönottovaiheeseen (11).

(11) Makarowin mukaan nyt odotellaan päätöksiä. Sivistysvaliokunnasta nimiasia etenee muiden yliopiston perustamiseen liittyvien lainsäädäntöhankkeiden ohella lopulta eduskunnan päätettäväksi. (HS 14.9.2017)

(12) - - se pitää huolella miettiä. Rakennamme uudenlaista yliopistoa, niin ei siihen olisi mitenkään voitu päästä heti, että se on jommankumman yliopiston nimi. Se ei olisi hyvin tehty. (AL 14.9.2017)

TTY:n rehtorin kommentti (12) muistuttaa, että nimen sulattelu vaatii aikaa.

Prosessin eri vaiheet ovat instituutioiden näkökulmasta välttämättömiä. Nimen hyväksyminen on askel kohti instituution hyväksyntää ja legitiimiä asemaa. Kansanonomastisen kehikon näkökulmasta (esim. Ainiala \& Halonen, 2011, s. 193-194) instituutioiden edustajat käyttävät nimiä ehdottaessaan ja niitä punnitessaan sekä metakieltä 1 että metakieltä 2. Edellisestä kertovat konkreettiset nimiehdotukset ja nimien kirjoitusasua sekä nimielementtejä koskevat kommentit, kuten esimerkeissä 6 ja 10, jälkimmäisestä puolestaan nimien tunnettuutta tarkastelevat kommentit, kuten esimerkissä 2 .

\subsection{Kielen asiantuntijat}

Yliopiston nimestä käytävän neuvottelun aikana annetaan ääni kielen asiantuntijoille vain yhtenä päivänä (ALb 8.10.2016). Lehti uutisoi ensin, että uuden instituution nimeksi tulee Tampere yliopisto. Vaikka kirjoitusvirhe korjattiin myöhemmin, saman päivän verkkolehteen oli haastateltu kahta suomen kielen asiantuntijaa, Sirkka Wahlsténia (W) ja Riitta Suomista (S).

Kielen asiantuntijoiden kannaksi ilmoitetaan, että uuden yliopiston nimen pitäisi olla Tampereen yliopisto (13). Mikäli heidän huonompana pitämänsä Tampere-yliopisto valitaan, tulee se kirjoittaa suomen ortografiasääntöjen mukaisesti (14):

(13) Kyllä Tampereen yliopisto on ehdottomasti paras vaihtoehto. (W) - - Jos minulta kysytään, niin Tampereen yliopisto. (S)

(14) Tampere-yliopisto on ainakin oikein kirjoitettu, kyllä se vaatii yhdysmerkin. (S) - - Tampere-yliopisto yhdysmerkillä on ehdottomasti parempi vaihtoehto kuin Tampere yliopisto, joka ei olisi ollut edes suomea. Mutta ei sekään hyvä ole. (W)

Kielen asiantuntijat ovat mediassa henkilöitä, joilla on mahdollisuus ja valta esittää jyrkkiä mielipiteitä. Vertailua paras korostetaan välttämättömyyttä ilmaisevalla modaaliadverbilla ehdottomasti. Norminvastainen kirjoitusasu saa jyrkän tuomion, koska se ei olisi ollut edes suomea. Lukijalle muodostuu kuva, että väärin kirjoitettu nimi ei ole kieltä ollenkaan.

Kielen asiantuntijat esittävät kolmenlaisia argumentteja Tampereen yliopiston puolesta ja 
vieraan mallin mukaisena pitämäänsä Tampere-yliopistoa vastaan. Oman kielen arvostus on tunteeseen perustuva argumentti (15). Haastateltavat käyttävät verbejä kunnioittaa, arvostaa ja huolehtia. Se, että nimet eivät noudata suomen ominaispiirteitä vaan saavat vaikutteita englannista, on kielen asiantuntijan suulla häpeilyä, jota pidetään yleisenä ongelmana:

(15) Suomessa pitää kunnioittaa suomen kieltä ja suomenkielisiä nimiä. (W) - Suomen kielen häpeily englannin rinnalla on pienen kielialueen ongelma. Omaa kieltä ei osata arvostaa eikä siitä huolehdita. $(S)$

Toinen, perustaltaan faktapohjainen, argumentti on vedota kielemme ominaispiirteisiin eli lähinnä siihen, että substantiivin määritteenä genetiivisijainen nominilauseke ilmaisee erilaisia kuuluvuussuhteita (ISK $₫ 1232$ ). Yhdysnimi, jonka määriteosa on nominatiivissa oleva propri, olisi toki mahdollinen, mutta silloin ilmauksen merkitys olisi tulkinnanvaraisempi (Itkonen, 2007, s. 27).

(16) Minä silti suosisin genetiiviä ja kirjoittaisin Tampereen yliopisto. - - Genetiivin karttelu on ollut yrityksissä pitkään suuntauksena. Suomen kielessä nimet kuitenkin taipuvat. - - Taivutuspäätteet ovat olennainen osa suomen kielen merkityksiä. (S)

Katkelmassa 16 Suominen käyttää minämuotoa, mutta konditionaali (suosisin) tuo lausumaan ohjailevaa sävyä. Tätä vahvistavat argumentit, jotka esitetään yleisinä faktoina: genetiiviä kartetaan yrityksissä, suomessa nimet taipuvat ja taivutuspäätteet ovat tärkeitä, koska niillä ilmaistaan merkityksiä.

Kolmas argumentti on tunnepohjainen: kielenkäyttäjien huomioon ottaminen. Kielenkäyttäjät eivät saa hämmentyä:
(17) Jos teemme kielen- ja suositustenvastaisia nimiä, lukijat ja kirjoittajat hämmentyvät. Se on käytettävyysongelma. (S)

Kielen asiantuntijat tukeutuvat siis kansanonomastisesti tarkasteltuna (esim. Ainiala \& Halonen, 2011, s. 193-194) useimmiten metakieleen 2: he kommentoivat nimien käyttöä ja käytettävyyttä. Heitä pyydetään mediassa kommentoimaan oikeinkirjoitusta, vaikka heidän olisi mahdollista puhua nimistä kielen sanoina yleisemminkin (vrt. metakieli 1). Tähän ei anneta kuitenkaan tilaa. Sen sijaan tämänsisältöistä “asiantuntijapuhetta” käyttää mm. toimittaja Kimmo Koski (AL 12.10.2016; ks. esim. 8). Lisäksi toimittaja Esa Keskinen istuttaa kieliasiantuntijan rooliin pysäköintipalveluyritys Finnpark Oy:n entisen toimitusjohtajan Markku Hiltusen ja yritysnimistä kirjan kirjoittaneen Timo Leppäsen, joita hän referoi Aviisissa 17.10.2016. Siinä kieliasiantuntijan ääni annetaan myös institutionaaliselle Patentti- ja rekisterihallitukselle (PRH). Näissä teksteissä suomen kieltä käsitellään paitsi vieraskielisten näkökulmasta fonologisesti myös nimien sisältämien sanojen merkityksen näkökulmasta. Mainituissa jutuissa argumentointi on pääosin tunnepitoista, eivätkä perustelut pohjau$\mathrm{du}$ faktoihin vaan puhujien mielipiteisiin tai asenteisiin (18-19). Kommenteissa korostuu vastakkainasettelu, jossa meillä "suomalaisilla" on kieli, jota muut, ulkomaalaiset, eivät osaa ääntää tai kirjoittaa:

(18) Kansainvälisesti suuntautuneen yliopiston nimen on oltava sellainen, että se sopii niin kiinalaisen, yhdysvaltalaisen kuin ranskalaisen suuhun. Tällainen ei "Tampere" todellakaan ole. Kovien konsonanttien ja vokaalien vaihtelu sekä lopun ärrä ovat lähes painajaismainen yhdistelmä monen suuhun. Kun ulkomaalainen sanoo sanan Tampere, ei edes suomalainen tunnista sitä. (AL 12.10.2016) 
(19) P-Hämppi avattiin marraskuun lopulla 2012. - - Hiltusen mukaan työnimenä käytetty P-Hämppi on huono nimi muun muassa siksi, että siinä on ulkomaalaisille hankala ä-kirjain. (Aviisi 17.10.2016)

Osin faktapohjaisia (esim. Sjöblom, 2006, s. 98-99) argumentteja esiintyy Leppäsen ja PRH:n referoinneissa. Rinnastamalla 1800-luvun lopun nimeämisperiaate ja 1900-luvun lopun trendi asetellaan vastakkain nimenantajan halu herättää positiivisia tunteita ja toisaalta vanhan nimen vaihtaminen uuteen, joka ei merkitse mitään (20). Kaupparekisterin suositukset (21) ovat taas lähes sellaisenaan luettavissa PRH:n verkkosivuilta (PRH.fi, nimiohjeet).

(20) 1800-luvun lopulla nimillä haluttiin herättää positiivisia kansallisia tunteita. Tästä ajasta esimerkkinä ovat kalevalaiset nimet Sampo, Pohjola ja Ilmarinen. Viime vuosisadan lopulla syntyi trendi, jossa vanhat yritykset vaihtoivat nimensä uusiin nimiin, jotka eivät välttämättä merkinneet mitään. (Aviisi 17.10.2016)

(21) PRH:n Kaupparekisteri suosittelee, että toiminimen kirjoitusasussa noudatetaan suomen kielen oikeinkirjoitussääntöjä. Kaupparekisteriin ei hyväksytä esimerkiksi pelkästään yleisiä etu- tai sukunimiä kuten Pekka Oy, yleistä paikannimeä kuten Pirkkala Oy, sanontaa tai lausahdusta tyyliin Meillä palvellaan asiakkaita Oy tai adjektiivia kuten Paras Oy. (Aviisi 17.10.2016)

Monissa sosiaalisen median kommenteissa esitetään kieleen liittyviä argumentteja. Aamulehden Facebook-sivuilla keskusteltiin 7.10.2016 lehdessä julkaistusta, aluksi "väärin" kirjoitetusta nimestä. Puheenvuorot ovat enimmäkseen reaktioita Tampere yliopisto- ja
Tampere-yliopisto-nimiasuja kohtaan. Kommentoijat asettuvat kielen asiantuntijan positioon käyttämällä tieteenalaan kuuluvia ja muita faktapohjaisia ilmauksia, kuten maamme kieli, tärkein opetuskieli, kieliopillisesti virbeellinen. Nominatiivialkuisen yhdysnimen ja genetiivimääritteisen sanaliiton merkityseroa pohditaan näennäisen objektiiviseen tyyliin, joskin poleemisesti (22-23):

(22) Jos se [yliopisto] tutkii vain Tamperetta niin silloin nimi olisi kai paikallaan, mutta kun opinahjon kotipaikka on Tampereella, niin oikeampi nimi on Tampereen Yliopisto, ja piste !!! (FB 7.10.2016)

(23) NN1: Nimi Tampere-yliopisto tuo mieleen, että tutkimuskohteena on vain Tampere. - -

NN2: Kyllähän Popedassa, Epuissa ja mustassa makkarassa riittäisi tutkittavaa.

NN3: Popeda ei liene enää Tampereen musiikillinen symboli, vaan Tampere-symbolimusiikki, mikäli yliopistoväki saa päättää. (FB 8.10.2016)

Kielestä esitetyissä kommenteissa näkyy ennen kaikkea ärtymys tai jopa tuohtumus ehdotettuja nimiä kohtaan. Sosiaalisen median kommentoijat asettuvat kielen asiantuntijan puhujapositioon eräänlaisiksi "kielipoliiseiksi”, mutta he eivät tehosta argumentointiaan väitteen esittäjän vakuuttavuutta lisäävällä retoriikalla vaan tunteisiin vetoavilla ilmaisuilla (naurettavalta, urpolta), kärjistyksillä (ei osata suomea), vertailuilla (byväksyttävämmän), konsensuksella (emme halua) ja lukijan puhuttelulla (miettikää). Esimerkissä 24 vastataan Aamulehden Facebook-toimittajan kysymykseen Miltä kuulostaisi Tampere yliopisto? 
(24) NN1: No aivan naurettavalta ja siltä, ettei osata suomea. En käsitä, miksei nimi voi vain olla Tampereen yliopisto, vaikka rakenne muuttuukin. Miettikää jos muutkin yliopistot tekisivät saman tempun perässä: "Helsinki yliopisto", "Jyväskylä yliopisto", "Itä-Suomi yliopisto" jne. Kuulostaa niin urpolta. Tuo perustelukin on kuin jokin aprillipila - miten se, että yliopiston nimi olisi englanniksi Tampere university, tekisi suomen kielessä Tampere yliopistosta yhtään sen hyväksyttävämmän muodon?

NN2: Yliopistolle ei ainakaan pitäisi antaa kieliopillisesti virheellistä nimeä!

NN3: Tavalta saada meidät ikiopiskelijat valmistumaan, koska emme halua nähdä CV:ssä kyseistä nimihirviötä. (FB 7.10.2016)

Huhtikuussa 2017 ehdotettu Tampereen uusi yliopisto -nimi herätti sosiaalisessa mediassa keskustelua myös kielestä. Tuohtumusta ilmennetään retorisilla kärjistyksillä (uskomatonta) ja huudahduksilla (byi hiisi). Argumentointi on tunnepitoista (25-26).

(25) NN1: Uskomatonta, että projektinimikin [Tampere3] on parempi kuin valittu nimi. Olisivat vaan nimenneet sen Tampereen yliopistoksi.

NN2: Ihan todella surkea nimi, mutta mitäpä Tampereelta voi odottaa....

NN3: Hyi hiisi! Jatkan vanhan opinahjoni kutsumista korkeakouluksi, kun en koskaan oikein oppinut käyttämään TTY:täkään. (FB 20.4.2017)

(26) Tampereen yliopiston kasvattina sanon, että tämä nimi on perseestä. (Twitter 20.4.2017)

Mediassa käydyssä keskustelussa mainitaan toisinaan myös uuden yliopiston englanninkielinen nimi Tampere University, josta jotkut esittävät kielenhuollollisiakin näkökulmia. Ruotsinkielisyys sivuutetaan kokonaan. Ainoastaan Helsingin Sanomat toteaa uutisessaan 14.9.2017: Ruotsinkielisestä nimestä suositusta ei annettu, vaan asiassa on tarkoitus kuulla eduskunnan kieliasiantuntijoita.

\subsection{Brändinrakentajat}

Uuden yliopiston muodostaminen herättää huolta myös instituution brändistä ja maineesta. Brändi on ennen kaikkea joukko mielikuvia, joiden tärkein konkreettinen ilmentymä on nimi (esim. Sjöblom, 2016, s. 454). Oikeastaan jo keskustelun käynnistänyt Aamulehden aprillijuttu nostaa esiin brändinäkökulman ironisoidessaan muodostettavan instituution nimestä käytävää kädenvääntöä:

(27) Kaikki alkaa nimestä. Sen pitää iskeä, - -Viestintätoimisto Succo Vedovotton graafikko klikkaa hiiren painiketta ja kiihkeä odotus päättyy. Tampereen tulevan jättiyliopiston logo heijastuu valkokankaalle. Samalla paljastuu yliopiston nimi: Moro University. (AL 1.4.2016)

Myös vakavasti otettavissa lehtijutuissa nimineuvottelua käydään brändinrakentajan positiosta. Tällöin etenkin nimikilpailut näkyvät instituution imagoa, tunnettuutta ja instituutioon sitoutumista edistävänä toimintana. Todetaan esimerkiksi, että nimenvalintaan vaikuttavat myös imagonmuodostuksen eli julkisuuskuvan hallitsevat brändiammattilaiset:

(28) Kun nimikilpailu päättyy, työryhmä kokoontuu brändiammattilaisten kanssa keskustelemaan nimiehdotuksista ja uuden yliopiston julkisuuskuvasta. (Aviisi 21.4.2016)

Myös toimittaja Kimmo Koski asettuu kommenttijutussaan vahvasti brändinrakentajan 
positioon (29). Hän vastustaa Tampere-nimen sisällyttämistä uuden yliopiston nimeen, koska yliopisto haluaa tulla tunnetuksi kansainvälisesti.

(29) Jos Tampereen korkeakoulun suuntana on maailma ja suurena tehtävänä on sen tunnetuksi tekeminen kansainvälisillä koulutusmarkkinoilla, yliopiston nimi ei voi alkaa Tampereella. Hallitukset ovat varmasti harkinneet Linnaa tai Viitaa Aallon tapaan, mutta tamperelaiset merkkihenkilöt ovat ehkä liian kirjallisia eivätkä he ole kansainvälisiä brändejä kuten Alvar Aalto. - - Tarinan kertomisen voimaa ei voi väheksyä, kun uutta yliopistoa myydään maailmalle. Koski kertoo tarinan vedestä, suomalaisten puhtaimmasta omaisuudesta. Koskessa on energiaa ja voimaa enemmän kuin yhdessä Aallossa. (AL 12.10.2016)

Toimittaja puhuu koulutusmarkkinoista ja yliopiston myymisestä maailmalle. Hän vertaa syntyvää yliopistoa ja sen nimeä vastaavasti fuusion kautta syntyneeseen Aalto-yliopistoon, jonka nimeen sisältyy kansainvälinen brändi, Alvar Aalto. Brändinrakentajan positiosta hän ehdottaa nimeä Koski ja siihen kytkettävää tarinaa, joka kertoo suomalaisten pubtaimmasta omaisuudesta, energiasta ja voimasta. Samalla hän asettaa nimen tavallaan kilpailemaan Aalto-yliopiston nimen kanssa.

Myös yhdistyvien instituutioiden edustajat argumentoivat välillä brändinrakentajan positiosta. Tampereen yliopiston rehtori Liisa Laakso (AL 14.9.2017) perustelee, miksi Koski-yliopisto putosi nimivaihtoehtojen joukosta, toteamalla, että uuden yliopiston brändä̈minen olisi vienyt aikaa ja ollut haastavaa. Samassa artikkelissa Tampereen teknillisen yliopiston rehtori Mika Hannula sanoo nimenmuutoksen vaikuttavan molempien yliopistojen brändiin.
Aviisi-lehden artikkelissa äänensä saa kuuluviin myös varsinaiseen brändiasiantuntijan rooliin asetettu palvelujen ja kaupan professori Hannu Saarijärvi Tampereen yliopistosta. Hänen sanomakseen voi tulkita kommentin (30), jossa argumentoidaan nimikilpailun puolesta viittaamalla epäsuorasti sanalla riski valitun nimen herättämään arvaamattoman kovaan vastustukseen. Jos ihmiset, kuluttajat, saavat itse vaikuttaa, he myös voivat sitoutua nimen ympärille rakennettavaan brändiin.

(30) Kilpailulla voi ulkoistaa nimen valintaan liittyvää riskiä. Toisaalta sillä voi myös sitouttaa kuluttajia omaan brändiin ja antaa heille mahdollisuuden vaikuttaa yrityksen toimintaan. (Aviisi 17.10.2017)

Lisäksi Saarijärven suuhun on sijoitettu suora sitaatti (31), joka lähestyy brändinrakennusta mainonnan näkökulmasta:

(31) - - se [nimikilpailu] on myös ilmaista mainosta. Nimikilpailut saavat helposti sekä perinteistä että sosiaalisen median julkisuutta, mikä edesauttaa uuden asian tunnettuutta. (Aviisi 17.10.2017)

Sosiaalisessa mediassa yliopiston brändiin ja maineeseen liittyy vain jokunen yksittäinen kommentti. Esimerkissä 32 kommentoija positioi itsensä brändiasiantuntijaksi predikatiiviadverbiaalilla markkinoijana.

(32) Ehdottomasti hieno suunta. Näin markkinoijana \#uusiyliopisto ei ollut paras mahdollinen nimi. (Twitter 28.4.2017)

\subsection{Paikallisuuden ystävät}

Paikallisuuden ystäviksi kutsumme niitä puhujia, jotka argumentoivat nimien maantieteellisen paikantavuuden ja ennen kaikkea paikallisiksi koettujen ilmiöiden, “tampere- 
laisuuden", puolesta. Kyse on otetusta puhujapositiosta, ja keskusteluun osallistutaan sosiaalisessa mediassa. Monet tuovat esiin oman ehdotuksensa yliopiston nimeksi. Nämä nimiehdotukset voidaan jakaa kolmeen ryhmään:

1. Tampere-nimen tai muun Tamperetta tarkoittavan nimen (Manse, Mansesteri) sisältävät nimet, muut paikalliseen nimistöön kytketyt nimet (Koski-elementin sisältävät nimet)

2. Tamperelaiseen kielimuotoon kytketyt nimet, joissa elementteinä ovat tervehdyssana moro, partikkeli nääs, linja-autoa tarkoittava nysse tai Hälläpyörä

3. Tamperelaisten kuuluisuuksien nimiä sisältävät nimet

Ehdotettujen nimien aineksia voidaan pitää Johnstonen (2010) kuvaamina paikallisuuden indekseinä, jotka rakentavat ja muokkaavat paikkoihin kytkettyjä merkityksiä ja sosiaalisia identiteettejä. Tästä positiosta nimiä koskeva puhe on kansanonomastisen kehikon kannalta metakieltä 1, siis ensisijaisesti itse nimiä ja nimielementtejä koskevaa (esim. Ainiala \& Halonen, 2011, s. 193-194). Keskustelijat tekevät nimiehdotuksia tai kommentoivat jo ehdotettuja nimiä, ja huomion kohteena on nimen leksikaalinen tai muu kielellinen sisältö ja ulkoasu.

Esimerkki 33 kuvastaa hyvin sitä, millä tavoin kirjoittajat tuovat esiin erilaisia paikallisiksi - kenties autenttisiksi tamperelaisiksi hahmottamiaan ilmiöitä. Aprillijutussa "uutisoitu” Moro University -nimi “viittaa sekä tamperelaiseen tervehdyssanaan että Italian entiseen pääministeriin Aldo Moroon" (AL 1.4.2016). Lehden Facebook-keskustelussa aprillipila tunnistetaan, mutta samalla leikillistä nimeä puolustetaankin. Keskusteli- jat nostavat vuorollaan esiin paikallisuuden elementtejä.

(33) NN1: Oikeasti Moro olisi kyllä yliopistolle ihan hyvä nimi!

NN2: Sopivampi nimi olisi Nääs tai Nysse University

NN3: olisin kyllä kannattanut raipeyliopistoa... (FB 1.4.2016)

Aprillipilan aineksena toiminut tervehdyssana moro yhdistetään valtakunnallisestikin Tampereeseen (esim. Lappalainen, 2009, s. 77). Lisäksi se koetaan niin vahvasti paikallisuutta ilmentäväksi, että se on otettu Tampereella hotellin baarin nimeksi (Moro Sky Bar ${ }^{1}$ ja Aamulehden paikallisuutisten osaston nimeksi². Myös partikkeli nääs on leimautunut tamperelaiselle kielimuodolle ominaiseksi, ja paikallista puhekieltä voidaan kutsua nääs-kieleksi (Mielikäinen \& Palander, 2014). Nysse-sana ('nyt se') taas tunnetaan linja-autoa merkitsevänä, ja Tampereen seudun joukkoliikennekin on ottanut sen nimekseen $^{3}$. Ei ole siis yllättävää, että juuri nääs ja nysse nousevat moron rinnalle, kun tuodaan ilmi alueelle miellettyjä ilmauksia.

Aineistomme keskusteluissa tuodaan esiin myös tamperelaisia kuuluisuuksia, joiden katsotaan ansaitsevan paikkansa yliopiston nimessä. Useimmat ehdotetut henkilöt eivät kuitenkaan kytkeydy yliopistomaailmaan. Monissa ehdotuksissa vilahtelee kolme tunnettua jääkiekkoilijanimeä: lempinimet $R a i$ pe (Raimo Helminen s. 1964) ja Juti (Timo Jutila s. 1963) sekä Laine (Patrik Laine s. 1998) (34).

\footnotetext{
1 https://www.raflaamo.fi/fi/tampere/moro-sky$\underline{\text { bar }}$

$\frac{2}{2}$ https://www.aamulehti.fi/moro

3 http://joukkoliikenne.tampere.fi/
} 
(34) NN: Kyllä sen pitäisi olla Laine yliopisto! Tietenkin Tampereen yliopisto on parempi kuin Tampereen uusi yliopisto, jos noista kahdesta pitää valita. Mutta miettikää vielä sitä Laine yliopistoa! (FB 20.4.2017)

Laine-sukunimen leksikaalinen vastine lienee vaikuttanut argumentointiin, jossa mallia on haettu Aalto-yliopistosta. Samaan semanttiseen kenttään kuuluu myös Koski-yliopisto $(8,29)$, joka myös nousee esiin paikallisuuden ystävien positiosta.

Yksittäisten jääkiekkoilijoiden lisäksi aineistossa esiintyy jääkiekkojoukkueen nimi Tappara. Lisäksi mainitaan kolme muusikkoa, Juice Leskinen, Pate Mustajärvi ja Dave Lindholm, sekä tv-viihdesarja Kummeli. Kirjailijoista huomion saavat Kalle Päätalo ja Väinö Linna, joiden kohdalla nimen asu ja semanttinen sisältö ovat voineet vaikuttaa ehdotuksiin ${ }^{4}$.

Moro-elementti yliopiston nimessä herätti keskustelua vielä myöhemminkin. Todennäköisesti Aamulehden aprillipilan motivoimana keksittiin nimi Moroversity, jossa voi halutessaan nähdä ilmaisun 'mor(e) over city'. Aamulehden 8.10.2016 (c) julkaisemassa lukijakyselyssä sai äänestää mieleistään nimeä. Lukijoista valtaosa kannatti nimeä Tampereen yliopisto (42\%), ja toiseksi tuli Moroversity (17\%). Jo hieman aiemmin Moroversity-nimen taakse oli alettu kerätä kannatusta adressit.com-sivustolla 5 , jossa esitettiin, että "Moroversity on paikallinen ja kansanomainen, mutta samalla kansainvälinen. Moroversityssä unohtuisivat nimeämisriidat ja valtataistelut. Tilalle leppoisa tunnelma, jossa perustutkimuksen louhiminen ja start-up pöhinöinti olisi yhtä juhlaa." Moroversity on otettu myös

4 Huom. myös Tampereen yliopiston kirjaston nimi on Linna.

5 https://www.adressit.com/tampereen_uuden_yliopiston nimeksi moroversity
Tampereen yliopistossa toimivan aktivistiliikkeen nimeksi ${ }^{6}$.

Nimineuvottelu jatkui Aamulehden Facebook-sivuilla, kun uutinen ehdotetusta Tampere-yliopisto-nimestä oli julkaistu. Nimeksi ehdotetaan Koski-yliopistoa, koska se noudattaisi muodoltaan ja semantiikaltaan Aalto-yliopiston nimeä ja toisi esiin keskeisen tamperelaisen luonnon maamerkin, Tammerkosken (35). Vaikka keskustelija ei esitä, että ehdotettu Tampere-yliopisto-nimi olisi vaikuttanut hänen kommenttiinsa, lienee tämä selvää. Seuraava keskustelija (NN2) tuo puolestaan esiin, luultavasti ironisesti, nimen Hälläpyörä-yliopisto osoittaen samalla olevansa tietoinen julkisuudessa käydystä keskustelusta. Kalevalassa mainitaan Hämeen Hälläpyörä, jonka arvellaan tarkoittavan Kyröskoskea. Tampereella on ollut myös tämän niminen ravintola, joka vuodesta 2010 on tunnettu Hällä-nimisenä.

\section{(35) NN1: Voisko olla Koski-yliopisto ?} Tammerkosken mukaan. Ois niinku Aalto -yliopiston kans linjassa

NN2: Hälläpyörä-yliopisto, hälläväliä, välimerkeillä tai ilman! (FB 8.10.2016)

Muutamaa päivää myöhemmin Aamulehden Facebook-sivuilla argumentoidaan paikkakunnan nimen sisältävien yliopistojen nimien puolesta (36).

(36) NN: Mä en ymmärrä miksi pitää kehittää jotain mukataiteellisia nimiä. Vanhat arvostetut yliopistot ympäri maailmaa on säilyttäneet nimessä paikkakunnan tms, miksi ihmeessä ei siis Suomessakin. Paikkakunta nimessä kertoo minkä kaupungin yliopisto on kyseessä. Ulkomaalaiselle ei Koski avaa ylipiston sijantia edes sen vertaa kun Tampere. Suomalaisetkin saa kohta kysellä missäs se Aalto, Koski, Laine ja Liplatus sijaitsikaan. (FB 12.10.2016)

6https://moroversity.wordpress.com 
Keskustelija vetoaa kansainväliseen perinteeseen ja kysyy, miksi tällaiset nimet eivät edelleen toimisi. Hänen mukaansa Koski-yliopisto ja muut mukataiteelliset nimet eivät toimisi paikantavana nimenä.

\subsection{Karnevalistit}

Nimineuvottelua käydään myös huumorin ja naurun kautta. Nauru aiheuttaa epävarmuutta, mikä tekee siitä tehokkaan vallan välineen (Bataille, 1998, s. 161). Karnevaalissa voi esittää kritiikkiä, mikä antaa mahdollisuuden uusiutumiseen (Bakhtin, 1984: 6). Karnevalistiksi positioidutaan naurun suoman ulkopuolisuuden ja puhdistavan voiman kautta. Yliopistofuusiossa rakennetaan uutta, mutta sekä uusiutumisen muoto (kuinka nimestä päätetään) että sisältö (mitä nimiä ehdotetaan) kyseenalaistetaan. Kansanonomastisesti tarkasteltuna karnevalistien nimiä koskeva puhe on, kuten paikallisuuden ystävilläkin, useimmiten metakieltä 1 (esim. Ainiala \& Halonen, 2011, s. 193-194), jossa huomion saavat itse nimet ja nimielementit

Näkyvimmin nimenantoprosessi karnevalisoidaan Aamulehden aprillijutussa, joka asettaa kyseenalaiseksi sekä fuusion että nimeämisprosessin (esim. 27, 37). Juttu saa vastakaikua sosiaalisessa mediassa $(38-40)$.

(37) - - Moro nääs, Lagonero tapailee manselaista puheenpartta - ja saa teknillisen yliopiston auditorioon kokoontuneet hörähtämään. (AL 1.4.2016)

(38) Juu ja lääkiksen nimeksi tulee "moriens". (Vanha viisas muistutus: "olet kuoleva") (FB 1.4.2016)

(39) Ihme, että Moro tuli valituksi, vaikka muitakin vaihtiksia oli tarjolla, $\mathrm{mm}$. LORO, VORO, JORO, TORO, HORO, NORO, KORO olisi ollut tarjolla (FB 1.4.2016)
(40) Kattellaa onko huomenna viel sama $\operatorname{nimi}(\mathrm{FB}$ 1.4.2016)

Huumorilla on laaja keinovalikoima. Paikallisuus lähentää ja synnyttää tunnistettavuutta: esimerkissä 37 toimittaja luo fiktiivisen tilanteen, jossa nauretaan oman kaupungin korkeakoulujen huvittavalta vaikuttavalle nimenantoprosessille. Tamperelaisuutta korostavat Moro nä̈̈s ja manselaista liitetään naurettavien asioiden joukkoon: ne saavat hörähtämään. Hirtehishuumoria näkyy esimerkissä 38, jossa Moroversitystä johdetaan allegoria moriens 'olet kuoleva'. Toistaminen on komiikan vahvoja keinoja, ja etukirjaimen muutoksella saadaan aikaan pitkä lista eri nimiversioita (39). Karnevalistien argumentointi perustuu siis tunteisiin, ja se ilmentää turhautuneisuutta (40).

Aprillijutussa brändiin liittyvät yliopistoinstituutioiden esittämät argumentit tulkitaan erityisen huvittaviksi. Nimen pitää iskeä (27), ja toiminta näyttäytyy suuruuden ihannointina: tase nousee 600 miljoonaan euroon - - kasvatamme panostuksemme jatkossa jopa kolminkertaiseksi (AL 1.4.2016). Naurajat ottavat etäisyyttä spektaakkelilta näyttävään fuusioon.

Lopulta uusi yliopisto päätyy nimeen Tampereen yliopisto, mikä saa toimittajan kyseenalaistamaan koko nimenantoprosessin (41).

(41) Säätiön hallitus jahkasi asiaa useissa kokouksissa kevään ja syksyn aikana. Lisäksi asian puimiseen on varmasti käytetty tunti jos toinenkin oppilaitosten käytävillä ja muissa tapaamisissa. Kahvia ja kampaviinereitä on kulunut.... Väitän, että samaan johtopäätökseen olisi päästy, jos nimiasia olisi käyty kysymässä keltä tahansa 4-vuotiaalta päiväkotilapselta. Eikä olisi maksanut mitään. (AL 15.9.2017). 
Nimenantoprosessista vastaavia instituutioedustajia väheksytään ilmaisuilla, kuten jabkasi, kevään ja syksyn aikana, tunti jos toinenkin, kabvia ja kampaviinereitä. Vallanpitäjien alentaminen, joka toteutuu viittauksessa päiväkotilapsiin, on keino ylentää omaa positiota. Raha on vahva fakta-argumentti, jolla kyseenalaistetaan nimeämisprosessin järkevyys: Eikä olisi maksanut mitään.

Nimenantoprosessin monet vaiheet inspiroivat myös opiskelijajärjestöjä humoristisiin kannanottoihin. Tampereen ei-turkulainen osakunta tiivistää näkemyksensä seuraavasti:

(42) Moitimme kuitenkin vahvasti koko nimenvalintaprosessia, koska nimeä valittaessa ei ole lainkaan huomioitu mahdollisia turkupoliittisia uhkakuvia tai edes konsultoitu turkupoliittisten uhkien asiantuntijoita, eli Ei-turkulaista osakuntaa. - - on päätynyt ehdottamaan uudeksi nimeksi Tampereen ei-turkulaista yliopistoa, englanniksi siis Tampere University of Not turku. Nimi yhdistää Tamperetta ja luo samalla vahvan me-hengen sisältämättä minkäänlaisia kyseenalaisia tai ristiriitaisia osia. (HS Nyt 21.9.2017)

Esimerkissä 42 otetaan haltuun instituutioiden itsensä käyttämää sanastoa (konsultoitu, asiantuntijoita) ja mukaillaan modernia organisaatiokieltä (turku-poliittisia ubkakuvia). Position edustaja käyttää kieltä, joka asemoi hänet akateemiseen kontekstiin: sisältämättäminkäänlaisia kyseenalaisia tai ristiriitaisia osia.

Karnevalistien argumentit ovat tunnepitoisia, mutta naurun voima tulee nähdä yliopistoille suunnatuksi kritiikiksi. Naurulla asetutaan vallanpitäjien yläpuolelle ja otetaan julkisuus ja nimenantoprosessi hetkeksi haltuun. Koko nimenantoprosessia ja erityisesti sen kriisivaiheita ajatellen karnevalistien merkitystä ei ole syytä väheksyä. Julkisesti ei ole kerrottu, mikä argumentti lopulta sai säätiöhallituksen muuttamaan mielensä ja vaihtamaan jo kertaalleen sovitun nimen. Äänekäs nauravien kuoro saattoi kuitenkin olla ratkaiseva. Nimenantoprosessin monet vaiheet heikensivät hetkeksi instituution hyväksyttävyyttä ja olivat konkreettisia osoituksia siitä, ettei uusi yliopisto ollut vielä täysin valmis.

\section{POHDINTA}

Tutkimuksemme on osoittanut, että uuden yliopiston syntyprosessi kytkeytyy nimenantoprosessiin ja nimestä mediassa käytävään neuvotteluun. Uutta yliopistoinstituutiota rakennettaessa nimestä tulee hankkeen menestyksen mittari ja legitimiteetin symboli. Nimi ja siitä käytävä keskustelu ilmentävät yhdistymiseen liittyviä vaikeuksia; toisaalta nimen tulisi heijastaa uutta yliopistoa, jota ei vielä ole, toisaalta nimen halutaan kuvastavan korkeakoulujen historiaa ja statusta. Sekä uutismedia että sosiaalinen media rakentavat uutta instituutiota nimen kautta. Nimen saama painoarvo yhdistymishankkeessa ei silti tyydytä kaikkia keskustelijoita.

Nimineuvottelussa puheenvuoroja esitetään sekä annetuista rooleista että otetuista positioista. Roolit ja positiot paljastuvat puheenaiheista, puhujien määrittelyistä ja kielellisistä valinnoista. Nimineuvottelua käydään instituutioiden, kielen, brändin, paikallisuuden ja karnevalistisen naurun näkökulmista. Roolit ja positiot ovat osittain päällekkäisiä, ja niiden voi myös katsoa muodostavan eräänlaisen jatkumon. Annetuissa rooleissa keskustellaan etenkin perinteisessä mediassa, ja otettujen positioiden puheenvuorot painottuvat sosiaaliseen mediaan. Eri nimiehdotuksia argumentoidaan eri tavoin roolin ja puhujaposition mukaan.

Kansanonomastinen kehikkomme osoittaa, että nimineuvottelussa esitetään sekä nimiä että nimien käyttöä koskevaa puhetta. 
Kielen asiantuntijoiden puheessa korostuu nimien käyttö, kun taas instituutioiden edustajat, brändinrakentajat, paikallisuuden ystävät ja karnevalistit tuovat vahvemmin esiin nimiä ja nimielementtejä koskevaa puhetta.

Nimikeskustelun saama suuri julkisuus viestii uutismedian logiikasta: sen lähes intuitiivisesta tavasta valita aiheet, jotka kiinnostavat ihmisiä. Nimikeskustelu osoittautuukin paitsi hyväksi esimerkiksi instituutioiden yhteen nivoutumisesta myös siitä, miten kieli rakentaa kulttuurisia merkityksiä ja ryhmäidentiteettejä monimuotoisessa mediamaastossa.

\section{LÄHTEET}

\section{Aineslähteet}

Aamulehti (AL): 1.4.2016, 8.10.2016 (a), 8.10.2016 (b; verkkolehti), 8.10.2016 (c; nimiäänestys), 12.10.2016, 20.4.2017, 14.9.2017, 7.9.2018

Aviisi: 12.4.2016, 21.4.2016, 14.9.2017, 17.10.2016

Helsingin Sanomat (HS): 25.5.2015, 20.4.2017, 14.9.2017

Yle: 30.9 .2016

Facebook (FB): 1.4.2016, 7.10.2016, 8.10.2016, 20.4.2017

Twitter: 5.4.2016, 8.10.2016, 28.4.2017

\section{Muut lähteet}

Ainiala, T. \& Halonen, M. (2011). Somalialaistaustaiset nuoret nimistönkäyttäjinä Itä-Helsingissä. Virittäjä, 115, 193-220.

Ainiala, T. \& Lappalainen, H. (2017). Orienting to norms: Variability in the use of names for Helsinki. Teoksessa T. Ainiala \& J.-O. Östman (toim.), Socio-onomastics. The pragmatics of names, (s. 129-153). Amsterdam: John Benjamins.

Ainiala, T., Saarelma, M. \& Sjöblom, P. (2008). Nimistöntutkimuksen perusteet. Helsinki: SKS.
Medialisoituminen näyttäytyy arvaamattomana päätöksentekoprosessina, jossa median valta korostuu ja perinteisten instituutioiden asema ainakin hetkeksi horjuu. Median kiinnostus nimeä kohtaan vaikuttaa siihen, mikä nimi uudelle yliopistolle lopulta valitaan. Sosiaalisten suhteiden verkostot eli ne alustat ja tilanteet, joissa nimiä arvotetaan, ovat olennainen osa julkisuudessa tapahtuvaa nimenantoprosessia. Instituution legitimiteettiä haetaan uskottavuuden ja hyväksynnän kautta, ja nimi osoittautuu tässä prosessissa hyväksi välineeksi.

Ainiala, T. \& Östman, J.-O. (2017). Introduction: Socio-onomastics and pragmatics. Teoksessa T. Ainiala \& J.-O. Östman (toim.), Socioonomastics. The pragmatics of names, (s. 1-18). Amsterdam: John Benjamins.

Aldrin, E. (2011). Namn som social handling. Valav förnamn och samtal om förnamn bland föräldrar i Göteborg. Uppsala: Uppsala universitet.

Aldrin, E. (2018). Naming, identity, and social positioning in teenagers' everyday mobile phone interaction. Names. A Journal of Onomastics. Haettu 23.1.2019 osoitteesta https://doi.org/ 10.1080/00277738.2017.1415523.

Bakhtin, M. (1984). Problems of Dostoeyvsky's poetics. Minneapolis: University of Minnesota Press.

Bataille, G. (1970/1998). Noidan oppipoika, kirjoituksia 1920-luvulta 1950-luvulle. Suomennos T. Arppe. Helsinki: Gaudeamus.

Bourdieu, P. (1991). Language and symbolic power. Cambridge: Polity Press.

Burke, K. (1962). A grammar of motives and a rhetoric of motives. Cleveland: World publishing company.

Couldry, N. \& Hepp, A, (2017). The mediated construction of reality. Cambridge: Polity Press. 
Fornäs, J. (2011). Medialisering av kultur, politik, vardag och forskning. Teoksessa J. Fornäs \& A. Kaun (toim.), Slutrapport frän Riksbankens Jubileumsfonds forskarsymposium i Stockholm (s. 5-13). Södertörn: Mediestudier vid Södertörns högskola.

Hakala, U., Sjöblom, P. \& Kantola, S.-P. (2015). Toponyms as carriers of heritage: implications for place branding. Journal of Product \& Brand Management, 24, 263-275.

Hjarvard, S. (2013). The mediatization of culture and society. London: Routledge.

Hämäläinen, A.-M. (2015). Itäkeskuksen lukiosta Helsingin kielilukioksi: lukion nimenmuutos ja opiskelijoiden näkemykset hyvästälukion nimestä. Pro gradu -tutkielma. Helsinki: Helsingin yliopisto. Haettu 23.1.2019 osoitteesta https:// helda.helsinki.fi/handle/10138/156539.

ISK = Iso suomen kielioppi. Hakulinen, A., Vilkuna, M., Korhonen, R., Koivisto, V., Heinonen, T. R. \& Alho, I. (2004). Helsinki: SKS.

Itkonen, T. (2007). Uusi kieliopas. Toim. S. Maamies. Helsinki: Tammi.

Johnstone, B. (2010). Indexing the Local. Teoksessa N. Coupland (toim.), Handbook of Language and Globalization (386-405). Oxford University Press.

Jokinen, A. (2002). Diskurssianalyysin suhde sukulaistraditioihin. - Jokinen, A., Juhila, K. \& Suoninen, E. (toim.), Diskurssianalyysi liikkeessä, (s. 37-53). (2. painos). Tampere: Vastapaino.

Kangasharju, H. (1991). Neuvottelu keskusteluna. Helsingin kauppakorkeakoulun julkaisuja B. Helsinki: Helsingin kauppakorkeakoulu.

Kotus.fi: oppilaitosten nimet $=$ https://www. kotus.fi/ohjeet/suomen_kielen_lautakunnan_ suosituksia/suositukset/oppilaitosten_nimet. Haettu 23.1.2019.

Kotus.fi: virallinen nimistö $=$ https://www. kotus.fi/kielitieto/nimisto/virallinen_nimisto. Haettu 23.1.2019.

Lappalainen, H. (2009). Hei, moi ja huomenta. Tervehdykset kioskilla. Teoksessa $\mathrm{H}$. Lappalainen \& L. Raevaara (toim.), Kieli kioskilla. Tutkimuksia kioskiasioinnin rutiineista, (s. 56-89). Helsinki: SKS.
Leino, A. (2014). Man, woman or me? Conflicting identities as evidenced by cross-gender name changes. Teoksessa J. Tort \& M. Montagut (toim.), Names in daily life: Proceedings of the XXIVICOS International Congress of Onomastic Sciences, 803-811. Barcelona: Generalitat de Catalunya.

Mielikäinen, A. \& Palander, M. (2014). Miten murteista puhutaan? Kansanlingvistinen sanakirja. Haettu 23.1.2019 osoitteesta https:// kielikampus.jyu.fi/mitenmurteistapuhutaan/.

Onkamo, U. (2017a). Kuta kovempi koulu, sitä nimi oudompi. (2017.) Haettu 23.1.2019 osoitteesta https://www.kotus.fi/nyt/ kotus-blogi/satunnaisesti_kirjoittava kotuslainen/kuta koulu kovempi sita nimi oudompi.22800.blog.

Onkamo, U. (2017b). Nimien perustelut puntarissa. (2017.) Haettu 23.1.2019 osoitteesta https://www.kotus.fi/nyt/kotusblogi/satunnaisesti_kirjoittava_kotuslainen/ nimien perustelut puntarissa.26764.blog.

Perelman, C. (1996). Retoriikan valtakunta. Suom. Leevi Lehto. Tampere: Vastapaino.

PRH.fi, nimiohjeet $=$ Patentti- ja rekisterihallitus, kaupparekisteri, yrityksen nimeä koskevat ohjeet. Haettu 23.1.2019 osoitteesta https://www.prh.fi/fi/kaupparekisteri/ yritystennimet/nimiohjeet.html.

Pälli, P. (2003). Ihmisrybmä diskurssissa ja diskurssina. Acta Universitatis Tamperensis 910. Tampere: Tampereen yliopisto.

Räisä, T. (2016). Medieritualer som klassoch kulturbundna diskurser och funktioner. Hufvudstadsbladets lucia och konstruktionen av Svenskfinland. Helsingfors: Helsingfors universitet.

Schmidt-Jüngst, M. (2015). Naming Choices of Transgender People in Germany. Teoksessa E. Aldrin, L. Gustafsson, M. Löfdahl \& L. Wenner (toim.), Innovationer i namn och namnmönster. Handlingar frain NORNA:s 43:e symposium $i$ Halmstad den 6-8 november 2013, (s. 234249). Uppsala: Norna-förlaget.

Sjöblom, P. (2006). Toiminimen toimenkuva. Suomalaisen yritysnimistön rakenne ja funktiot. Helsinki: SKS. 
Sjöblom, P. (2016). Commercial names. Teoksessa C. Hough (toim.), The Oxford handbook of names and naming, (s. 453-464). Oxford University Press.

Sjöblom, P. \& Hakala, U. (2018). Toponyms and place heritage as sources of place brand value. Onomastica Uralica, 10, 137-148.

SKS = Suomalaisen Kirjallisuuden Seura, Helsinki.

Sommerfeldt, K.-E. (1994). Schulnamen in den neuen Bundeslandern nach der Wende. Teoksessa K.-E. Sommerfeldt (toim.), Sprache im Alltag. Beobachtungen zur Sprachkultur, (s. 221-229). Frankfurt am Main: Peter Lang.

Sumiala, Johanna (2012). Median rituaalit. Johdatus media-antropologiaan. Tampere: Vastapaino.

Virsu, V. (2007). Sosiaalisten ongelmien retoriikkaa: tapaus doping. Virittäjä, 111 , 346-366.

Yliopistolaki 558/2009. Finlex. Haettu 23.1.2019 osoitteesta www.finlex.fi/fi/laki/ ajantasa/2009/20090558. 


\section{NAMING PROCESS OF A NEW INSTITUTION IN MEDIA PUBLICITY IN THE LIGHT OF SPEAKERS' ROLES, POSITIONS AND ARGUMENTS}

Terhi Ainiala, University of Helsinki

Tiina Räisä, Arcada University of Applied Sciences

Paula Sjöblom, University of Turku

In this article, we study the naming process of a new institution in media publicity. The starting point of the study is the fusion of three Finnish universities of the city of Tampere - University of Tampere, Tampere University of Technology and Tampere University of Applied Sciences - during 2016-2017. Our empirical material consists of texts gathered from traditional news media and social media.

In the naming negotiation, statements are expressed both from roles given by media and from self-selected positions. Roles and positions are to be seen through the selection of topics, the speakers' definitions and lexical choices. The negotiation for the name runs from standpoints of institution, language, branding, localness, and carnivalistic laughter. Especially in the traditional news media, people and institutions discuss about names from roles given by media, whereas the self-selected positions are more obvious on the social media platforms. Media's interest in the university name affects the outcome of the name negotiation and the final name choice.

Keywords: discourse, institution, medialization, name, position 